\title{
Gender diversity on corporate boards: How Asian and African women contribute on sustainability reporting activity
}

\author{
Antonella Francesca Cicchiello and Anna Maria Fellegara \\ Faculty of Economics and Law, Catholic University of the Sacred Heart, \\ Piacenza, Italy \\ Amirreza Kazemikhasragh \\ University Program of Studies on Asia and Africa (PUEAA), \\ National Autonomous University of Mexico, Mexico City, Mexico, and \\ Stefano Monferrà \\ Faculty of Economics and Law, Catholic University of the Sacred Heart, \\ Piacenza, Italy
}

\begin{abstract}
Purpose - This study aims to investigate the influence of organisations' board gender diversity on the adoption of the United Nations sustainable development goals (SDGs) and on the use of external assurance.

Design/methodology/approach - The paper combines data from the Global Reporting Initiative's Sustainability Disclosure Database and the Orbis database from Bureau van Dijk. The study uses logit models based on a sample of 366 large Asian and African companies which have addressed the SDGs in their sustainability reports published in 2017.

Findings - The results reveal that board gender diversity is positively associated with sustainability reporting and the involvement of an external assurance provider.

Originality/value - This study adds to the growing literature on the relationship between women's participation on corporate boards and SDG reporting. Additionally, it addresses the understudied question of how the gender diversity of board resources affects the adoption of the external assurance of sustainability reporting.
\end{abstract}

Keywords Female directors, Sustainability reporting, Board gender diversity, External assurance

Paper type Research paper

\section{Introduction}

Over the past few years, sustainability disclosure has become a promising and growing trend amongst developing countries (Jamali and Karam, 2018).

(C) Antonella Francesca Cicchiello, Anna Maria Fellegara, Amirreza Kazemikhasragh and Stefano Monferrà. Published by Emerald Publishing Limited. This article is published under the Creative Commons Attribution (CC BY 4.0) licence. Anyone may reproduce, distribute, translate and create derivative works of this article (for both commercial and non-commercial purposes), subject to full attribution to the original publication and authors. The full terms of this licence may be seen at http://creativecommons.org/licences/by/4.0/legalcode

JEL classification - L2, M14, P48, Q01

Received 12 May 2020 Revised 13 January 2021 26 February 2021 Accepted 12 March 2021 
GM

36,7

802

This is partly due to governments' recognition of the importance of sustainability in supporting the long-term growth and development of these countries where social and environmental problems are unique and significant (Tilt et al., 2020). Both local and foreign investors increasingly set a high value on transparency and allocate capital based on sustainability considerations. Therefore, the importance of sustainability reporting is growing and the need to ensure the attractiveness of developing countries where investment opportunities are accompanied by higher degrees of uncertainty and even controversy.

Due to the weakness of the institutions, firms operating in developing countries are often the most vulnerable to unethical corporate practices (Yasser et al., 2017). Sustainability activities and practices make companies more responsible not only towards the shareholders but also towards other affected stakeholders which have started to exert pressure on firms to behave appropriately. Furthermore, sustainability practices signal firms' competitiveness and improves the reputation, legitimacy and social acceptance they need to be successful (Bear et al., 2010; Hahn and Kühnen, 2013).

This translates into greater value (Kuzey and Uyar, 2017) and better performance (Ameer and Othman, 2012).

Policymakers in Africa and Asia have started promoting sustainable business practices through the adoption of new mechanisms (e.g. the establishment of a Corporate Social Responsibility [CSR] Committee which members have an exclusive focus on targets and deliverables) and strategic frameworks aimed at achieving inclusive and sustainable development to ensure better governance and sustainability (Mahmood et al., 2018).

Both African and Asian countries have committed to implement the sustainable development goals (SDGs) of the United Nations (UN) through national development plans aimed at raising awareness amongst government officers, members of Parliaments, civil society and private sector actors; thereby translating these goals into tangible outcomes.

Introduced in 2015 by the UN Procurement Division, the SDGs consist of a set of 17 global goals structured into 169 ambitious targets to be reached by 2030. An initiative taken in 2018 by two of the major providers of sustainability reporting guidance has allowed companies to incorporate SDGs into their existing reporting processes (Global Reporting Initiative, 2018).

As a consequence, an increasing number of companies on these territories are actively demonstrating their social commitment and responsibility in behaviour through sustainability reporting (Tilt et al., 2020).

As previous studies have shown, having more women on boards positively influence firms' reporting activities because of their greater sensitivity to social and ethical issues and their increased awareness of environmental risks (Girón et al., 2020). Unlike prior research on gender effects in sustainability practices which are predominantly based on developed countries, there is a paucity of research on the impact of board gender diversity on sustainability reporting in developing countries, especially in African and Asian regions (Tilt et al., 2020).

These regions represent an interesting context for the research on sustainability reporting for the following reasons.

Firstly, like most developing countries, Africa and Asia are characterised by historical gender inequalities in many areas of life, such as health, education, employment and earnings. The patriarchal nature of these societies, especially in low- and middle-income countries, poses obstacles to women's economic development and confines them to domestic and familial roles (World Economic Forum, 2018).

Although an increasing number of women are serving on the boards of companies, empirical evidence shows that female boardroom appointments in most Asian and African countries continue to be very low compared to Western nations. In Africa, women are barely present in boardrooms where 95\% of Chief Executive Officer (CEO) are men. Only 25\% of 
women access board committees, only $24 \%$ of women hold middle-management positions and only $12.7 \%$ of women hold the board seats in Africa's top listed companies (FraserMoleketi et al., 2015). Gender diversity is improving across businesses in the Asian emerging markets. Women hold $9.3 \%$ of board seats and fill $4.2 \%$ of board chair positions, an increase of $1.5 \%$ and $1.6 \%$ from 2016, respectively (Deloitte, 2019).

In particular, in the Philippines, the number of companies without female directors fell significantly from $26 \%$ in 2019 to $14 \%$ in 2020 . The number of Taiwanese companies with male-only boards shrank by $5 \%$ in 2020 . In China, the average percentage of women on boards has remained low; $13.0 \%$ in 2020 signifying only 1.6\% more than in 2019 .

Secondly, because of different institutional, political, social and cultural contexts, the effects of corporate governance attributes such as board gender diversity on sustainability reporting are expected to vary between developed and developing countries. The latter is also facing increasing pressures from foreign investors, international media and stakeholders to improve governance implementation and to initiate sustainability policies and procedures consistent with those adopted in developed economies (Ali et al., 2017).

Given the paucity of empirical evidence, investigating board gender diversity in emerging countries is crucial to providing a deep understanding of the impact that board gender diversity has on sustainability reporting practices.

In light of this, the purpose of this study is to investigate how board gender diversity influence the adoption of new sustainability reporting practices (i.e. SDG reporting) by large companies in the lower-middle-income countries in Asia and Africa [1].

Additionally, this article addresses the understudied question of how the gender diversity of board resources affects the adoption of the external assurance of sustainability reporting made by professional accountants which can enhance the credibility of sustainability reports and increase stakeholders' confidence (Peters and Romi, 2015).

To the best of our knowledge, this paper is the first to provide recent evidence on the effect of board gender diversity on sustainability reporting and external assurance in large organisations in the low and middle-income countries in Asia and Africa.

Through its findings, this work makes it possible to identify the characteristics that differentiate the African and Asian environment from other environments with regard to the firms' choice to adopt an external assurance for sustainability reports. It also contributes to the agency and stakeholder theories by showing how the corporate governance characteristics and stakeholders' pressure influence firms in their choice to voluntarily assure sustainability reports.

\section{Theoretical background}

\subsection{Gender diversity on boards and sustainability reporting}

Over the past years, the literature has recognised that gender diversity on the board of directors (BoD) plays a vital role in firms' choice of sustainability engagement (Velte, 2017; Nguyen et al., 2020). Corporate boards with greater gender diversity are more socially responsible. Even the presence of a single female board member can make a difference, especially in male-dominated industries (Zaichkowsky, 2014).

Firstly, female directors differ from male directors in terms of personality, educational background and career experience (Liao et al., 2015).

Women have different communication and leadership styles compared to their male counterparts (Bear et al., 2010); they are more ethically sensitive and empathetic and more socially responsible than men (Setó-Pamies, 2015), who are generally more performanceoriented (Rao and Tilt, 2015). 
GM

36,7

804

Gender-diverse boards exhibit greater concern for social and ethical issues and are more engaged in corporate philanthropy and in corporate social behaviour and responsibility including charitable giving, social investments, community involvement and outside recognition of employee benefits (Williams, 2003). Post et al. (2011) show that boards composed of three or more female directors are more likely to implement environmental governance structures or processes. In its study, Haque (2017) reveals that board gender diversity has a positive association with carbon reduction initiatives launched by non-financial UK firms over the period 2002-2014. Relying on stakeholder and institutional theory, Yasser et al. (2017) investigate the relationship between board gender diversity and corporate social performance of firms across the Asia Pacific emerging economies. The authors find that female directors have a greater communal orientation and stronger moral standards and ethical stances than male directors. Thus, greater gender diversity on the BoD enhance firms' adoption of CSR.

Furthermore, greater female participation in the $\mathrm{BoD}$ is associated with a significantly higher value of sustainability-related investments and greater efficiency in reporting. According to Arayssi et al. (2016), this increases firms' performance and reduces their risks. McGuinness et al. (2017) analyse the relationship between the top-management officer gender and CSR performance in Chinese firms. The authors show that board gender diversity promotes firms' social performance and that stronger incremental rating effects emerge when female leadership accompanies board gender mix.

Secondly, female directors are more stakeholder-oriented; therefore, their presence increases the ability of boards to recognise and satisfy the interests of a variety of stakeholder groups, thus positively affecting the quality (Harjoto et al., 2015; García-Sánchez et al., 2019) and quantity (Rao et al., 2012; Fernandez-Feijoo et al., 2014a, 2014b) of information disclosed by companies in their sustainability reporting.

Harjoto et al. (2015) show that board diversity enhances US firms' ability to satisfy the needs of their broader groups of stakeholders, thereby significantly increasing CSR performance. Analysing a sample of companies listed on the Pakistan Stock Exchange, Mahmood et al. (2018) reveal that a large board size mostly made up of female directors, along with the presence of a CSR Committee improves management decisions regarding sustainability issues by ensuring a better sustainability disclosure. Using an international sample of 273 firms, García-Sánchez et al. (2019) reveal that a greater female representation on the $\mathrm{BoD}$ increases the quality of sustainability reporting in terms of balance, comparability and reliability of the information, especially in firms located in more stakeholder-oriented countries. Fernandez-Feijoo et al. (2014a, 2014b) find empirical evidence that countries with a higher proportion of $\mathrm{BoD}$ with at least three women produce higher levels of CSR reporting. By examining the annual reports of firms listed on the Australian Stock Exchange, Rao et al. (2012) find a significant positive relationship between the extent of environmental reporting and the proportions of female directors on boards. Similarly, Elmagrhi et al. (2016) show that UK firms with greater director gender diversity tend to disclose more corporate governance information voluntarily. In a recent study, Issa and Fang (2019) find a significant relationship between the number of female directors and the level of CSR disclosure in the Arab Gulf states.

The participation of women members on corporate boards encourage the effectiveness of the firm's monitoring and increasing the efficiency of social disclosure (Arayssi et al., 2016). This enhances public perceptions of the board's legitimacy and trustworthiness, improves the credibility of corporate reports and strengthens the reputation of the company. Using data from the US, Bear et al. (2010) reveal that the number of women on the board has a positive impact on firms' CSR ratings and contributes to enhancing corporate reputation.

Gender diversity in the $\mathrm{BoD}$ is also associated with proactive social and environmental policies, practices and reporting (Glass et al., 2015). According to Glass et al. (2015), firms 
with a greater proportion of women leaders (i.e. women CEOs and women on the BoD) are more likely to pursue environmentally-friendly strategies. Kilic et al. (2015) find that the presence of female directors increases CSR disclosure in the Turkish banking industry. Similarly, Jizi (2017) finds that UK firms with higher female participation tend to establish ethical policies and are more engaged in sustainability reporting. Anazonwu et al. (2018) confirm the positive influence of female managers on sustainability reporting in a sample of Kenyan banks and Nigerian manufacturing companies, respectively.

In a recent study, Rosati and Faria (2019) reveal the existence of a positive relationship between a high share of female directors and the early adoption of SDG reporting in a sample of 408 organisations worldwide.

Thirdly, women are generally more risk-averse than men (Jianakoplos and Bernasek, 1998) and are more inclined to engage in less risky activities (Adams and Ferreira, 2009). In the sphere of sustainability reports, this translates into greater information transparency and a lower risk of manipulating corporate financials or other disclosures (Barua et al., 2010; Ho et al., 2014).

Moreover, gender-diverse boards tend to have a higher perception of environmental risks and take actions to reduce stakeholders' perceived risks (Liao et al., 2015).

In their study, García-Sánchez et al. (2019) find that the lower risk aversion of female directors, along with their conservative approach and their ethical commitment, decrease the risk of impression management strategies in sustainability disclosure by reducing the risk of alteration of information. Female directors are indeed positively associated with more balanced and reliable information. Gul et al. (2011), argue that female directors exhibit greater risk aversion and ethical behaviour. They are also better at obtaining voluntary information contributing to a reduction of information asymmetry.

Liao et al. (2015) find that large companies in the UK with greater board gender diversity are more likely to disclose extensive reports on greenhouse gas emissions to reduce stakeholders' perceived risks. Based on a sample of listed Canadian firms, Ben-Amar et al. (2017) find evidence of greater risk awareness of women directors whose presence increases firms' likelihood to voluntarily disclose information about climate change-related risks.

In their study, Saggar and Singh (2017) show that board gender diversity positively affects voluntary disclosure of risk information in the annual reports of Indian listed companies. Female directors are also more averse to litigation and reputation loss and therefore are likely to act more decisively than their male counterparts in improving corporate sustainability (Srinidhi et al., 2011). The results from the study of Tauringana et al. (2017), for example, suggest that the presence of a woman on the board decreases the likelihood of a firm being convicted of an environmental offence in the UK. By analysing the link between women on boards of directors and corporate sustainability, Galbreath (2011) finds that board gender diversity promotes "good" governance; thereby minimising the effects of subversion or misappropriation of shareholder funds.

Despite their individual limitations, these studies collectively reveal that the presence of women on the $\mathrm{BoD}$ encourages firms to ethically manage their social responsibilities and sustainable reporting practices.

Despite the growing literature on sustainability practices, the relationship between board gender diversity and sustainability reporting is a relatively unexplored area amongst developing countries, especially in the Asian and African regions (Tilt et al., 2020).

Much attention should therefore be paid to the relationship between these two concepts which are closely related to each other.

Hence, consistent with the previous literature review and its findings, this paper explores the impact of board gender diversity on SDG reporting by proposing the following hypothesis: 
GM

36,7
H1: Organisations that contain a higher proportion of women on the $\mathrm{BoD}$ are more likely to address the SDGs in their sustainability reports.

\subsection{Gender diversity on boards and external assurance}

To ensure transparency and enhance the credibility of their sustainability reports, companies may voluntarily choose to assure their reports through external assurance services designed to result in published conclusions on the quality of the report and the information included within it (Global Reporting Initiative, 2013).

External assurance services are a type of independent professional service aimed at improving the robustness, accuracy and trustworthiness of information disclosed in sustainability reports. These services are typically provided by certified or chartered providers with expertise and competency in sustainability management processes and disclosures.

External assurance service providers are generally divided into three groups: accountancy firms, engineering firms and small consultancy firms.

Accountancy firms (e.g. Deloitte, Ernst and Young, KPMG, Lloyds and PricewaterhouseCoopers) are large consulting firms connected to a global network of professional services consisting of firms both owned and managed independently. These firms are specialists in financial and non-financial reporting and normally have their own systems, controls and audit/assurance procedures. Engineering firms offer technical certifications and engineering expertise. These firms usually understand complex processes and are used to risk-based analysis. Finally, small consultancy firms (also called boutiques) are smaller than the other assurance providers and offer a limited number of services to a relatively local client base. The assurance process is an integral part of the whole reporting process. The role of the assurance provider is to provide external verification of reporting and the processes behind reporting through the drafting of an assurance report or statement that may be disclosed as part of the sustainability reporting process. About $40 \%$ of sustainability reports issued by large corporations on an international level are assured by external independent experts (Kolk and Perego, 2010). Sustainability reports that have been externally assured are seen as more robust and reliable (Simnett et al., 2009).

The literature on sustainability reporting analysing the effect of board gender diversity on the adoption of external assurance is in its infancy and academic contributions are still rare (Velte and Stawinoga, 2017).

Liao et al. (2018), for example, examine the association between corporate boards and a company's decision to obtain CSR assurance. The authors find that Chinese listed firms with more female directors are more likely to engage in CSR assurance. In a sample of international firms, García-Sánchez et al. (2019) find empirical evidence that female directors show a greater orientation towards the provision of assurance statements in CSR reports to increase their credibility.

Previous literature shows that a greater presence of women in the $\mathrm{BoD}$ increases firms demands to audit efforts and managerial accountability (Adams and Ferreira, 2009).

Therefore, we expect firms with more female directors to be more likely to engage in external assurance.

Thus, we hypothesise that: 
H2: Organisations that contain a higher proportion of women on the $\mathrm{BoD}$ are more likely to adopt external assurance of their sustainability reports.

\section{Data and methodology}

\subsection{Data sources and sample}

This paper explores the relationship between board gender diversity and SDG reporting in Africa and Asia using hand-collected data from two sources: The Global Reporting Initiative's (GRI's) Sustainability Disclosure database and the Bureau van Dijk's Orbis database.

The GRI database displays all types of sustainability reports, whether GRI guidelinesbased (e.g. G3, G3.1 and G4) or otherwise and relevant information related to the reporting organisations, indicating for each of them the presence of any explicit reference to the SDGs. This allowed us to extract data about large organisations in low and middle-income countries in Asia and Africa (i.e. countries with a GNI per capita between $\$ 996$ and $\$ 3,895$ ) which have published a sustainability report following the G4 Sustainability Reporting Guidelines in the year 2017 [2]. From the GRI database, we obtained an initial sample of 369 organisations with full information about their name, the sector, the originating country and the explicit reference to or the application in the sustainability reports of the following standards and principles:

- the IFC (International Finance Corporation) performance standards on environmental and social sustainability;

- the UNGC (United Nations Global Compact) and its 10 principles in the areas of human rights (Principles 1 and 2), labour (Principles 3, 4, 5 and 6), environment (Principles 7, 8 and 9) and anti-corruption (Principle 10);

- the ISO 26000 clauses addressing the following seven core subjects of social responsibility: organisational governance, community involvement and development, human rights, consumer issues, labour practices, the environment and fair operating practices;

- the UN SDGs.

Finally, we collected information about the adoption of external assurance of sustainability reports.

The names of the 369 organisations extracted from the GRI database were then matched with entries in the Orbis database to gather data on the organisations' corporate governance (i.e. the number of employees, the number of directors on the board, the percentage of female directors and the average age of the $\mathrm{BoD}$ ) and on their economic and financial performance (i.e. total assets $[A S S E T]$, market capitalisation $[C A P]$, operation revenue, return on equity $[R O E]$, return on assets $[R O A]$, Tobin's $\mathrm{Q}$ and profit margins [PMs]). After combining the two databases, we obtained a final sample of 366 observations.

The characteristics of the sample by region, country and industry, are presented in Table 1.

\subsection{Method of analysis}

To measure the relationship between board gender diversity and the adoption of SDG reporting and external assurance, we run two logit models with the following specification: 
GM

36,7

\begin{tabular}{lr}
\hline Region & $N(\%)$ \\
\hline Asia & $316(86)$ \\
Africa & $50(14)$
\end{tabular}

Country

Bangladesh

Cambodia

4 (1.09)

$1(0.27)$

Cote d'Ivoire

$2(0.55)$

Egypt

India

$3(0.82)$

Indonesia

39 (10.66)

Kenya

42 (11.48)

$1(0.27)$

Madagascar

$1(0.27)$

Mainland China

68 (18.58)

Malaysia

$15(4.1)$

Marocco

$1(0.27)$

Nigeria

$5(1.37)$

$4(1.09)$

Philippine

$11(3.01)$

South Africa

$33(9.02)$

Sri Lanka

39 (10.66)

Thailand

61 (16.67)

Turkey

Uganda

$20(5.46)$

$1(0.27)$

Viet Nam

$12(3.28)$

Zimbabwe

$3(0.82)$

Industry

Agriculture

$6(1.64)$

Automotive

$15(4.1)$

Aviation

$5(1.37)$

Chemicals

9 (2.46)

Commercial services

$2(0.55)$

Computers

$1(0.27)$

Conglomerates

$15(4.1)$

Construction

12 (3.28)

Construction materials

9 (2.46)

Consumer durables

$1(0.27)$

Energy

$28(7.65)$

Energy utilities

$11(3.01)$

Equipment

$2(0.55)$
$90(24.59)$

Financial services

Food and beverage products

17 (4.64)

Forest and paper products

$17(4.64)$
$3(0.82)$

Health-care products

$8(2.19)$

Health-care services

$3(0.82)$

Household and personal products

$1(0.27)$

Logistics

$8(2.19)$

Media

Metals products

$3(0.82)$

Mining

8 (2.19)

Other

$23(6.28)$

$24(6.56)$

Public agency

$1(0.27)$

Railroad

Real estate

$1(0.27)$

Retailers

$10(2.73)$

$5(1.37)$

Technology hardware

$3(0.82)$

Telecommunications

$23(6.28)$

Textiles and apparel

$12(3.28)$

Tobacco

$1(0.27)$

Tourism/leisure

$1(0.27)$

$\begin{array}{ll}\text { Waste management } & 1(0.27)\end{array}$

Table 1. Waste management

$4(1.09)$

Characteristics of the

Total

366 (100) 
$S D G s=\left\{\begin{array}{c}1 \text { if } \beta_{0}+\beta_{1}(\text { size })+\beta_{2}(\text { eper })+\beta_{3}(\text { tobq })+\beta_{4}(\text { sus })+\beta_{5}(\text { gov })+\varepsilon \\ 0 \text { otherwise }\end{array}\right.$

EXTASS $=\left\{\begin{array}{c}1 \text { if } \beta_{0}+\beta_{1}(\text { size })+\beta_{2}(\text { eper })+\beta_{3}(\text { tobq })+\beta_{4}(\text { sus })+\beta_{5}(\text { gov })+\varepsilon \\ 0 \text { otherwise }\end{array}\right.$

The dependent variable of the first model is "SDGs" - a dichotomous variable denoting 1 for organisations addressing the UN SDGs in their sustainability report and 0 otherwise.

The dependent variable of the second model is "EXTASS" (external assurance statement) - a dummy variable denoting 1 when organisations decide to assure voluntarily their sustainability reports through external assurance providers and 0 otherwise.

Prior studies have suggested that larger companies need to meet higher expectations of the public by exhibiting a greater inclination towards more sustainable initiatives compared to smaller companies (Zhang, 2012; Arayssi et al., 2016). Therefore, we include three variables to represent the size and importance of the organisations (size): total assets ("ASSET"); number of employees ("EMP"); and market capitalisation (“CAP"). We expect that organisations with a larger size are more likely to adopt sustainability reporting and external assurance, given the greater pressure they face from stakeholders (Reverte, 2009).

Several studies have indicated that sustainability reporting is positively associated with companies' financial performance (Hahn and Kühnen, 2013). High profitability increases the company ability to bear the costs of sustainability reporting and to face any negative consequences related to the disclosure of harmful information.

Therefore, we use three proxies for firm financial performance (eper):

(1) profit margins (" $P M$ "), is the ratio of the net income to the revenue and measures a company's earnings (or profits) relative to its revenue;

(2) Return on Assets ("ROA"), is the ratio of net income to the book value of the firms' assets; and

(3) Return on Equity (" $R O E$ "), is the ratio of net income to the value of the total shareholders' equity.

We use Tobin's q (“TOBQ") to represent the organisations' market-based performance (tobq). Tobin's $\mathrm{Q}$ is the ratio of the market value of a company's assets to the replacement value of those assets and measures the wealth generated by a company for its shareholders. It compares how much more a company is worth when compared to the book value of its assets. A Tobin's Q above one indicates that the company is worth more than the sum of its assets.

All these variables have been extensively used in the empirical literature as a proxy for firm performance (Zhang, 2012; Arayssi et al., 2016; amongst others).

A number of dummy variables were used to represent the organisations' commitment to additional sustainability standards and frameworks (sus) that can influence the adoption of SDGs reporting and external assurance: "UNGC", "IFC" and "ISO".

Some of the most important corporate governance variables mentioned in the literature were used to represent the diversity in the $\mathrm{BoD}$ (gov): "FEMALE" (measured as the percentage of women on the $\mathrm{BOD})$, "CEODUA" (CEO duality), "BSIZE" (the number of directors on the board), " $A G E$ " (the average age of the $\mathrm{BoD}$ ). 
GM

36,7

As women tend to have more ethical behaviours and demand a higher level of sustainability (Issa and Fang, 2019), we expect a higher proportion of female directors to increase the likelihood of organisations addressing the SDGs in their sustainability reports and adopting external assurance.

According to the agency theory, the characteristics of the board can affect the decision of a company to engage in sustainability reporting (Jizi, 2017).

Therefore, we consider the duality of functions of CEO and Chairman of the board by including the variable "CEODUA" - a dummy variable equals to 1 whether the chairman of the $\mathrm{BoD}$ is also the $\mathrm{CEO}$ and 0 otherwise. The presence of a single individual holding the role of both the CEO and chairman of the board could compromise the effectiveness of board monitoring and influence managers to disclose less information (Sellami et al., 2019). Based on the above arguments, we expect the combined roles of CEO and chairman to adversely affect sustainability reporting quality and external assurance.

According to previous studies, the smaller size of BoDs ensures better communication between the participants and a greater commitment to sustainability (Arayssi et al., 2016; Osazuwa et al., 2016). We, therefore, include the "BSIZE" (board size) variable measured by the number of directors on the board, expecting to find a positive relationship between a lower number of directors on the board and the adoption of sustainability reporting and external insurance.

Finally, we consider the effect that board age can have on sustainability reporting and external assurance by including the variable " $A G E$ " measured by the average age of the members of the BoD. In line with the literature (Post et al., 2011; Rosati and Faria, 2019), we expect that the presence of younger directors has a positive influence on the adoption of SDGs practices and external assurance as younger individuals tend to be more sensitive to environmental issues.

To account for potential differences in the adoption of sustainability reporting and external assurance, we include two dummy variables relating to organisations' regions of provenance ("ASIA" and "AFRICA").

Previous studies showed that the industry has a significant effect on the environment and therefore can influence the sustainability reporting practices of the companies that operate there (Branco and Rodrigues, 2008; Simnett et al., 2009).

In industries considered riskier to the environment, stakeholders exert strong pressure on companies which consequently tend to increase the level of transparency of their sustainability reports compared to companies in other sectors (Lattemann et al., 2009; Broberg et al., 2010; Fernandez-Feijoo et al., 2014a).

In the same way, some previous studies (Cho et al., 2014; Sellami et al., 2019) showed that companies belonging to environmentally sensitive industries are more prone to assure their sustainability reports to improve their image and ability to deal with the greater pressure from consumers to sustainability concerns.

Thus, we control the industry effect by including the following variables:

- “CPI” (Customer Proximity Industries) - a dummy variable equals to 1 for organisations operating in industries with high consumer closeness (i.e. energy utilities, financial services, food and beverage products, healthcare, household and personal products, retailers, telecommunications, textiles and apparel, waste management and water utilities), and 0 otherwise;

- “ESI" (Environmentally Sensitive Industries) - a dummy variable equals to 1 for organisations operating in industries that have an important impact on the environment (i.e. agriculture, automotive, aviation, chemical, construction, construction materials, energy, energy utilities, forest and paper products, logistics, 
metal products, mining, railroad, waste management and water utilities) and 0 otherwise.

Data sources and variables' descriptions are presented in Table 2.

Table 3 reports the summary statistics. As shown in the table, only $33 \%$ of the organisations used SDGs guidelines and a very low percentage of organisations used the UNGC, CDP and IFC standards and principles (25\%, $12 \%$ and $0.03 \%$, respectively). Moreover, $86 \%$ of the organisations in the sample are located in Asia (only $14 \%$ in Africa), Gender
diversity on
corporate
boards $40 \%$ operate in customer proximity industries, whilst $60 \%$ operate in environmentally sensitive industries.

\begin{tabular}{|c|c|c|c|c|}
\hline Variable & Symbol & Description & Data sources & \\
\hline \multicolumn{5}{|l|}{ Dependent variable } \\
\hline SDGs & $S D G$ & $\begin{array}{l}\text { Dummy variable equals to } 1 \text { whether the } \\
\text { organisation reports with addressing SDGs and } 0 \\
\text { otherwise }\end{array}$ & GRI & \\
\hline $\begin{array}{l}\text { External assurance } \\
\text { statement }\end{array}$ & EXTASS & $\begin{array}{l}\text { Dummy variable equals to } 1 \text { whether the } \\
\text { sustainability reporting is verified by an external } \\
\text { assurance provider and } 0 \text { otherwise }\end{array}$ & GRI & \\
\hline \multicolumn{5}{|l|}{ Explanatory variables } \\
\hline Employees & $E M P$ & Number of employees & Orbis & \\
\hline Asset & ASSET & Total assets & Orbis & \\
\hline Capitalisation & CAP & Market capitalisation & Orbis & \\
\hline Profit margins & $P M$ & Profit margins & Orbis & \\
\hline CEO duality & CEODUA & $\begin{array}{l}\text { Dummy variable equals to } 1 \text { whether the chairman } \\
\text { of the board of directors is also the } \mathrm{CEO} \text { and } 0 \\
\text { otherwise }\end{array}$ & Orbis & \\
\hline ROE & $R O E$ & Return on equity & Orbis & \\
\hline ROA & $R O A$ & Return on assets & Orbis & \\
\hline Tobin's Q & $T O B Q$ & Market capitalisation/total assets & Orbis & \\
\hline Board Size & $B S I Z E$ & Number of directors on the board & Orbis & \\
\hline UNGC & $U N G C$ & $\begin{array}{l}\text { Dummy variable equals to } 1 \text { whether the } \\
\text { organisation reports with addressing UNGC and its } \\
\text { principles and } 0 \text { otherwise }\end{array}$ & GRI & \\
\hline IFC & $I F C$ & $\begin{array}{l}\text { Dummy variable equals to } 1 \text { whether the } \\
\text { organisation uses IFC standards and } 0 \text { otherwise }\end{array}$ & GRI & \\
\hline ISO & ISO & $\begin{array}{l}\text { Dummy variable equals to } 1 \text { whether the } \\
\text { organisation uses ISO clauses and } 0 \text { otherwise }\end{array}$ & GRI & \\
\hline $\begin{array}{l}\text { Customer proximity } \\
\text { industries }\end{array}$ & CPI & $\begin{array}{l}\text { Dummy variable equals to } 1 \text { whether the } \\
\text { organisation operates in industries with high } \\
\text { consumer closeness and } 0 \text { otherwise }\end{array}$ & GRI & \\
\hline $\begin{array}{l}\text { Environmentally sensitive } \\
\text { industries }\end{array}$ & ESI & $\begin{array}{l}\text { Dummy variable equals to } 1 \text { whether the } \\
\text { organisation operates in industries with a high } \\
\text { impact on the environment and } 0 \text { otherwise }\end{array}$ & GRI & \\
\hline Africa & AFRICA & $\begin{array}{l}\text { Dummy variable equals to } 1 \text { whether the } \\
\text { organisation is located in Africa and } 0 \text { otherwise }\end{array}$ & GRI & \\
\hline Asia & $A S I A$ & $\begin{array}{l}\text { Dummy variable equals to } 1 \text { whether the } \\
\text { organisation is located in Asia and } 0 \text { otherwise }\end{array}$ & GRI & \\
\hline Female & FEMALE & Percentage of female members on $\mathrm{BoD}$ & Orbis & Table 2. \\
\hline $\begin{array}{l}\text { Number of female } \\
\text { directors }\end{array}$ & $n F E M$ & Number of female members on BoD & Orbis & $\begin{array}{r}\text { Description of } \\
\text { variables and data }\end{array}$ \\
\hline Age & $A G E$ & The average age of members of $\mathrm{BoD}$ & Orbis & sources \\
\hline
\end{tabular}


GM

\begin{tabular}{|c|c|c|c|c|c|c|}
\hline 36,7 & Variable obs. & $\mathrm{N}$ & Mean & Std. dev & Min & $\operatorname{Max}$ \\
\hline \multirow{5}{*}{812} & SDGs & 366 & 0.327869 & 0.470079 & 0 & \\
\hline & EXTASS & 366 & 0.363388 & 0.481634 & 0 & 1 \\
\hline & $T O B Q$ & 268 & 0.801791 & 1.504502 & 0 & 15.52 \\
\hline & $E M P$ & 243 & $27,081.65$ & $62,661.88$ & 3 & 449,296 \\
\hline & BSIZE & 365 & 37.37475 & 30.74684 & 1 & 150 \\
\hline & $\begin{array}{l}A S S E T \\
C A P\end{array}$ & $\begin{array}{l}257 \\
268\end{array}$ & $\begin{array}{l}3,810,426 \\
6933292\end{array}$ & $\begin{array}{c}1.41 \mathrm{E}+07 \\
1841916\end{array}$ & $\begin{array}{r}24.81 \\
235\end{array}$ & $1.99 \mathrm{E}+08$ \\
\hline & $\begin{array}{l}C A P \\
P M\end{array}$ & $\begin{array}{l}268 \\
326\end{array}$ & $\begin{array}{c}\text { 6,933.292 } \\
15.75015\end{array}$ & $\begin{array}{c}18,419.16 \\
19.79561\end{array}$ & $\begin{array}{r}2.35 \\
-84.71\end{array}$ & $\begin{array}{c}208,120.3 \\
90.75\end{array}$ \\
\hline & $R O E$ & 328 & 17.15576 & 44.15562 & -337.94 & 512.68 \\
\hline & & 329 & 4.243161 & 6.832613 & -13 & 60 \\
\hline & UNGC & 366 & 0.254098 & 0.435949 & 0 & 1 \\
\hline & $I F C$ & 366 & 0.032787 & 0.178322 & 0 & 1 \\
\hline & ISO & 366 & 0.15847 & 0.365681 & 0 & 1 \\
\hline & & 366 & 0.3945205 & 0.489418 & 0 & 1 \\
\hline & & 366 & 0.6054795 & 0.489418 & 0 & 1 \\
\hline & AFRICA & 366 & 0.863013 & 0.344304 & 0 & 1 \\
\hline & ASIA & 366 & 0.136986 & 0.344304 & 0 & 1 \\
\hline & FEMALE & 366 & 0.14987 & 0.110712 & 0 & 1 \\
\hline & $A G E$ & 352 & 58.42898 & 5.783419 & 41 & 71 \\
\hline
\end{tabular}

\section{Results}

Table 4 shows the results of the econometric analysis with the dependent variable "SDG" (Model 1) and "EXTASS" (Model 2).

$H 1$ predicts that the presence of women on the $\mathrm{BoD}$ fosters organisations' adoption of SDGs in sustainability reports. The results indicate the gender of the directors is significantly related to the likelihood that large organisations in the low and middle-income countries in Asia and Africa address SDGs in their sustainability reports. Specifically, results show that a higher percentage of women directors in the $\mathrm{BoD}$ strengthens the adoption of SDG reporting (Female, $\mathrm{b}=0.15, p<0.1$ ) supporting $H 1$.

Our findings confirm previous studies on board gender diversity according to which a greater female representation on BoDs increases the adoption of new sustainability reporting practices (Setó-Pamies, 2015; Arayssi et al., 2016).

$H 2$ predicts that the presence of women on the $\mathrm{BoD}$ fosters organisations' decision to voluntarily include external independent assurance in their sustainability reports. In line with previous studies (Al-Shaer and Zaman, 2016), our results indicate that a higher percentage of women directors is positive and statistically significant related to the organisations' decision to adopt external assurance of their sustainability reporting (Female, $\mathrm{b}=0.11, p<0.05)$. Hence, $H 2$ is also supported.

Furthermore, our findings suggest that increased board size has no influence on SDG reporting; however, it encourages the adoption of external assurance. Looking at the average age of the $\mathrm{BoD}$, we find a positive and statistically significant relationship with both dependent variables. This means that younger boards of directors (on average) are more prone to adopt SDG reporting and external assurance. Finally, we do not find statistically significant empirical evidence that CEO duality influences the adoption of SDG reporting and external assurance.

Regarding the control variables, our results are generally consistent with those obtained from previous studies. In line with the stakeholders' theory and previous studies 


\begin{tabular}{|c|c|c|c|c|c|c|c|}
\hline Independent variables & $\begin{array}{l}\text { Model } 1 \\
\text { SDGs }\end{array}$ & $\begin{array}{c}\text { Model } 2 \\
\text { EXTASS }\end{array}$ & $\begin{array}{c}\text { Robustness } \\
\text { check (Model 1) } \\
\text { SDGs }\end{array}$ & $\begin{array}{c}\text { Signs } \\
\text { predicted }\end{array}$ & $\begin{array}{c}\text { Robustness } \\
\text { check (Model 2) } \\
\text { EXTASS }\end{array}$ & $\begin{array}{c}\text { Signs } \\
\text { predicted }\end{array}$ & $\begin{array}{l}\text { Gender } \\
\text { diversity on } \\
\text { corporate }\end{array}$ \\
\hline FEM & $\begin{array}{c}0.1531223^{*} \\
(0.0425299)\end{array}$ & $\begin{array}{l}0.1086442^{* * *} \\
(0.5016859)\end{array}$ & $\begin{array}{c}0.1549532^{*} \\
(0.0468549)\end{array}$ & + & $\begin{array}{c}0.1163569^{* * *} \\
(0.5133716)\end{array}$ & + & boards \\
\hline CEODUA & $\begin{array}{c}-0.0374401 \\
(0.2938991)\end{array}$ & $\begin{array}{c}0.0116731 \\
(0.2799343)\end{array}$ & $\begin{array}{r}-0.0348594 \\
(0.2924452)\end{array}$ & + & $\begin{array}{c}0.0119365 \\
(0.2801951)\end{array}$ & + & \\
\hline$E M P$ & $\begin{array}{c}0.1081344 \\
(0.1939226)\end{array}$ & $\begin{array}{c}0.0246532 \\
(0.1735671)\end{array}$ & $\begin{array}{c}0.1102573 \\
(0.1915472)\end{array}$ & + & $\begin{array}{c}0.0279931 \\
(0.1768955)\end{array}$ & + & 813 \\
\hline ASSET & $\begin{array}{c}0.0630528^{*} \\
(0.1322854)\end{array}$ & $\begin{array}{l}0.0335867^{*} \\
(0.1408563)\end{array}$ & $\begin{array}{l}0.0646879^{* * *} \\
(0.1298745)\end{array}$ & + & $\begin{array}{l}0.0378566^{*} \\
(0.1396596)\end{array}$ & + & \\
\hline$P M$ & $\begin{array}{l}0.0469957^{* * *} \\
(0.0197352)\end{array}$ & $\begin{array}{l}0.0206862^{* * *} \\
(0.0098756)\end{array}$ & $\begin{array}{l}0.0478865^{* * *} \\
(0.0213547)\end{array}$ & + & $\begin{array}{l}0.0237994^{* * *} \\
(0.0116589)\end{array}$ & + & \\
\hline BSIZE & $\begin{array}{c}0.0096249 \\
(0.0141454)\end{array}$ & $\begin{array}{l}0.0248965^{*} \\
(0.0049878)\end{array}$ & $\begin{array}{c}0.0102334^{*} \\
(0.0168452)\end{array}$ & + & $\begin{array}{l}0.0256113^{*} \\
(0.0085652)\end{array}$ & + & \\
\hline$R O A$ & $\begin{array}{r}-0.0941452^{*} \\
(0.0585094)\end{array}$ & $\begin{array}{c}0.02493327 \\
(0.0729844)\end{array}$ & $\begin{array}{r}-0.0953201^{*} \\
(0.0568514)\end{array}$ & - & $\begin{array}{c}0.0216569^{*} \\
(0.0688965)\end{array}$ & - & \\
\hline$R O E$ & $\begin{array}{l}0.0484118^{* * *} \\
(0.0235586)\end{array}$ & $\begin{array}{c}0.01496533^{*} \\
(0.0399985)\end{array}$ & $\begin{array}{l}0.0492354^{* * *} \\
(0.0245236)\end{array}$ & + & $\begin{array}{c}0.0186647^{*} \\
(0.0423233)\end{array}$ & + & \\
\hline$T O B Q$ & $\begin{array}{c}0.1443527^{*} \\
(0.1745933)\end{array}$ & $\begin{array}{c}0.1018957 \\
(0.1844965)\end{array}$ & $\begin{array}{c}0.1479653^{*} \\
(0.1723265)\end{array}$ & + & $\begin{array}{c}0.0113236 \\
(0.1936536)\end{array}$ & + & \\
\hline$C A P$ & $\begin{array}{r}-0.0198818^{*} \\
(0.0123558)\end{array}$ & $\begin{array}{c}0.0098659^{*} \\
(0.0103565)\end{array}$ & $\begin{array}{r}-0.0199931^{*} \\
(0.0135248)\end{array}$ & - & $\begin{array}{c}0.0081769^{*} \\
(0.0196354)\end{array}$ & - & \\
\hline AGE & $\begin{array}{l}0.0066081^{* * *} \\
(0.0012564)\end{array}$ & $\begin{array}{c}0.01396589^{*} \\
(0.0109663)\end{array}$ & $\begin{array}{c}0.0084502^{* * *} \\
(0.0014569)\end{array}$ & + & $\begin{array}{c}0.0169941^{*} \\
(0.0114963)\end{array}$ & + & \\
\hline UNGC & $\begin{array}{l}0.8809067^{* * *} \\
(0.2696426)\end{array}$ & $\begin{array}{c}0.55068863^{*} \\
(0.3089665)\end{array}$ & $\begin{array}{l}0.8849866^{* * *} \\
(0.2765438)\end{array}$ & + & $\begin{array}{c}0.5633989^{*} \\
(0.3194318)\end{array}$ & + & \\
\hline $\mathrm{IFC}$ & $\begin{array}{c}0.54368518 \\
(0.4168518)\end{array}$ & $\begin{array}{c}0.7768989 \\
(0.4846569)\end{array}$ & $\begin{array}{c}0.5513659 \\
(0.4054837)\end{array}$ & + & $\begin{array}{c}0.7956371 \\
(0.4996537)\end{array}$ & + & \\
\hline ISO & $\begin{array}{c}-0.2998531 \\
(0.3487315)\end{array}$ & $\begin{array}{c}0.1186598 \\
(0.4088659)\end{array}$ & $\begin{array}{c}-0.2963251 \\
(0.3596524)\end{array}$ & + & $\begin{array}{c}0.1235964 \\
(0.4179846)\end{array}$ & + & \\
\hline CPI & $\begin{array}{l}1.4269857^{* * *} \\
(0.8087712)\end{array}$ & $\begin{array}{l}0.6496662^{* * *} \\
(0.4796589)\end{array}$ & $\begin{array}{l}1.4396555^{* *} \\
(0.8235369)\end{array}$ & + & $\begin{array}{l}0.6536533^{* * *} \\
(0.4913615)\end{array}$ & + & \\
\hline ESI & $\begin{array}{l}1.5719654^{* * *} \\
(0.8793254)\end{array}$ & $\begin{array}{l}0.7386598^{* * * *} \\
(0.5089656)\end{array}$ & $\begin{array}{l}1.5946537^{* * *} \\
(0.8917366)\end{array}$ & + & $\begin{array}{l}1.7388961^{* * *} \\
(0.5133497)\end{array}$ & + & \\
\hline $\begin{array}{l}\text { Country control } \\
\text { Robustness } \\
\text { Check by regions }\end{array}$ & controlled & controlled & controlled & & controlled & & \\
\hline $\begin{array}{l}\text { Pseudo } R^{2} \\
p \text {-value }\end{array}$ & $\begin{array}{l}0.047 \\
0.000\end{array}$ & $\begin{array}{l}0.052 \\
0.00\end{array}$ & & & & & $\begin{array}{r}\text { Table } 4 . \\
\text { Results of statistical }\end{array}$ \\
\hline \multicolumn{7}{|c|}{ Notes: ${ }^{*} p$ value $<0.1$ and ${ }^{* *} p$ value $<0.05$} & analysis \\
\hline
\end{tabular}

(Fernandez-Feijoo et al., 2014a; Sellami et al., 2019) who confirm that the pressure of customers enhances the level of transparency of sustainability reporting, our results show that the CPI variable influences SDG reporting and sustainability assurance demand. Organisations in industries with high consumer closeness are likely to enhance their reputation by adopting SDG reporting and external assurance.

In the same vein, our results reveal that the ESI variable is positively and significantly correlated with both dependent variables. This confirms that organisations may decide to adopt SDG reporting and sustainability assurance to reduce the public awareness of the larger effect of the industry on the environment.

Regarding financial performance, we find a significant positive correlation between PM, SDGs and external assurance. This can be due to the use of high technology or smart marketing by organisations that leads to higher commitment and sustainable development. ASSET and the ROE have a significant positive impact on both dependent variables. The results relating to CAP show a mixed relationship with our dependent variables. Finally, we 
GM

36,7

814

find a direct and positive relationship between Tobin's q and SDG reporting. These results confirm several studies in the prior literature (see, for example, Cohen et al., 2012; Sharif and Rashid, 2014).

We run the robustness check to control coefficient estimates' behaviour when adding regions (Neumayer and Plümper, 2017). Following Lu and White (2014), we use the "Checkrob" command on Stata. Our findings show that the coefficients do not change much. The region has a minimal positive impact on all coefficients except for CAP and ROA. The very small changes in the coefficients confirm that the results are valid and robust. The coefficients explain the dependent variables by plausible arguments. As we expect from the previous results, board resources' gender diversity affects the adoption of SDG reporting and the external assurance of sustainability reporting. Also, we control for the country.

Finally, to verify the robustness of our findings we carried out an additional analysis by using the number of women on the board " $n F E M$ " instead of the percentage as the main independent variable. Models 3 and 4 show that our results hold when we use a different variable for women on boards (Table 5). When we run the robustness check, the coefficients do not change much.

\section{Discussion and conclusions}

Sustainability reporting and its external assurance has acquired growing importance on organisations, especially for those operating in developing countries which are often the most vulnerable to unethical corporate practices. As the issuance of sustainability reporting has grown significantly over the past few decades, customers, investors and other stakeholders are increasingly demanding more transparency on the information disclosed by organisations in their reports. From this perspective, the assurance process, aimed at the verification of sustainability reports by external independent experts, becomes more and more a fundamental requirement to reduce information asymmetry and strengthen stakeholders' confidence in the reliability and credibility of corporate disclosure (Bepari and Mollik, 2016). Because of their psychological and emotional characteristics, women tend to be more socially oriented and more sensible towards the interests of others than men (Tourigny et al., 2017).

Therefore, the presence of women directors can influence firms' engagement in sustainable business practices, social reputation and stakeholder needs (Issa and Fang, 2019).

In this study, we set out to investigate the relationship between the board gender diversity and the adoption of new sustainability reporting practices (i.e. SDG reporting) and external assurance in large organisations operating in low and middle-income countries in Asia and Africa. In particular, the goal of this study is to understand whether a higher proportion of female directors could represent an opportunity for large Asian and African organisations to raise the quality of their ethical behaviour.

Our paper presents some major findings and provides some new theoretical insights, as discussed below.

Firstly, this study contributes to the growing literature on sustainability reporting providing evidence from large companies in the lower-middle-income countries in Asia and Africa.

Although prior research provides valuable discussions of the potential benefits of female directors on firms' ethical behaviour, the impact of board gender diversity on SDGs and external assurance in African and Asian lower-middle-income countries has not yet been investigated (Tilt et al., 2020). 


\begin{tabular}{|c|c|c|c|c|c|c|c|}
\hline Independent variables & $\begin{array}{l}\text { Model } 3 \\
\text { SDGs }\end{array}$ & $\begin{array}{c}\text { Model } 4 \\
\text { EXTASS }\end{array}$ & $\begin{array}{c}\text { Robustness check } \\
\text { (Model 3) } \\
\text { SDGs }\end{array}$ & $\begin{array}{c}\text { Signs } \\
\text { predicted }\end{array}$ & $\begin{array}{c}\text { Robustness } \\
\text { check (Model 4) } \\
\text { EXTASS }\end{array}$ & $\begin{array}{c}\text { Signs } \\
\text { predicted }\end{array}$ & $\begin{array}{l}\text { Gender } \\
\text { diversity on } \\
\text { corporate }\end{array}$ \\
\hline$n F E M$ & $\begin{array}{c}0.1443749^{* *} \\
(0.0493233)\end{array}$ & $\begin{array}{l}0.0909356^{* *} \\
(0.0644969)\end{array}$ & $\begin{array}{c}0.1449346^{* * *} \\
(0.0494937)\end{array}$ & + & $\begin{array}{c}0.0939691^{* *} \\
(0.0665151)\end{array}$ & + & boards \\
\hline CEODUA & $\begin{array}{c}-0.0226118 \\
(0.1872746)\end{array}$ & $\begin{array}{c}0.0100653 \\
(0.2786662)\end{array}$ & $\begin{array}{c}-0.0246632 \\
(0.1893799)\end{array}$ & + & $\begin{array}{c}0.0136969 \\
(0.2833129)\end{array}$ & + & \\
\hline$E M P$ & $\begin{array}{c}0.0899653 \\
(0.1722685)\end{array}$ & $\begin{array}{c}0.0263589 \\
(0.1703566)\end{array}$ & $\begin{array}{c}0.0934598 \\
(0.1749668)\end{array}$ & + & $\begin{array}{c}0.0293323 \\
(0.1743561)\end{array}$ & + & 815 \\
\hline ASSET & $\begin{array}{l}0.0619874^{* * *} \\
(0.1239658)\end{array}$ & $\begin{array}{l}0.0433849^{* * *} \\
(0.0906965)\end{array}$ & $\begin{array}{l}0.0643265^{* * *} \\
(0.1316659)\end{array}$ & + & $\begin{array}{l}0.0491603^{* * *} \\
(0.0928694)\end{array}$ & + & \\
\hline$P M$ & $\begin{array}{l}0.0389565^{* *} \\
(0.0449856)\end{array}$ & $\begin{array}{l}0.0341356^{* * *} \\
(0.0239564)\end{array}$ & $\begin{array}{l}0.0395656^{* * *} \\
(0.0436294)\end{array}$ & + & $\begin{array}{l}0.0371965^{* * *} \\
(0.0259659)\end{array}$ & + & \\
\hline BSIZE & $\begin{array}{l}0.03492537^{*} \\
(0.0176568)\end{array}$ & $\begin{array}{l}0.0545563^{*} \\
(0.0306959)\end{array}$ & $\begin{array}{c}0.0377656^{*} \\
(0.0192429)\end{array}$ & + & $\begin{array}{c}0.0548965^{*} \\
(0.0310063)\end{array}$ & + & \\
\hline$R O A$ & $\begin{array}{r}-0.1143781^{*} \\
(0.0765895)\end{array}$ & $\begin{array}{c}0.0513356^{*} \\
(0.0409635)\end{array}$ & $\begin{array}{r}-0.1196113^{*} \\
(0.0810065)\end{array}$ & - & $\begin{array}{c}0.0518553^{*} \\
(0.0418659)\end{array}$ & - & \\
\hline$R O E$ & $\begin{array}{c}0.07865966^{* *} \\
(0.0642989)\end{array}$ & $\begin{array}{c}0.0538895^{*} \\
(0.0340697)\end{array}$ & $\begin{array}{c}0.0819668^{* * *} \\
(0.0696772)\end{array}$ & + & $\begin{array}{c}0.0559659^{*} \\
(0.0349659)\end{array}$ & + & \\
\hline$T O B Q$ & $\begin{array}{c}0.1244634^{*} \\
(0.1467731)\end{array}$ & $\begin{array}{c}0.0696632 \\
(0.1009346)\end{array}$ & $\begin{array}{c}0.1300651^{*} \\
(0.1516894)\end{array}$ & + & $\begin{array}{c}0.0715232 \\
(0.1058751)\end{array}$ & + & \\
\hline$C A P$ & $\begin{array}{r}-0.0104195^{*} \\
(0.0094532)\end{array}$ & $\begin{array}{l}0.01433635^{*} \\
(0.0117961)\end{array}$ & $\begin{array}{r}-0.0109333^{*} \\
(0.0106639)\end{array}$ & - & $\begin{array}{l}0.01426356 * \\
(0.0117565)\end{array}$ & - & \\
\hline$A G E$ & $\begin{array}{c}0.0101585^{* *} \\
(0.0119658)\end{array}$ & $\begin{array}{l}0.0142362^{*} \\
(0.0129695)\end{array}$ & $\begin{array}{l}0.0126859^{* * *} \\
(0.0129333)\end{array}$ & + & $\begin{array}{c}0.0143901^{*} \\
(0.0136589)\end{array}$ & + & \\
\hline$U N G C$ & $\begin{array}{l}0.7868579^{* * *} \\
(0.3839971)\end{array}$ & $\begin{array}{c}0.5098563^{*} \\
(0.2930965)\end{array}$ & $\begin{array}{l}0.7973874^{* * *} \\
(0.4006354)\end{array}$ & + & $\begin{array}{l}0.5119087^{*} \\
(0.3003561)\end{array}$ & + & \\
\hline$I F C$ & $\begin{array}{c}0.5906598 \\
(0.4909689)\end{array}$ & $\begin{array}{c}0.8144361 \\
(0.5369697)\end{array}$ & $\begin{array}{c}0.5999123 \\
(0.5063561)\end{array}$ & + & $\begin{array}{l}0.8168956 \\
(0.546595)\end{array}$ & + & \\
\hline ISO & $\begin{array}{c}-0.2086661 \\
(0.2579965)\end{array}$ & $\begin{array}{c}0.0811569 \\
(0.3711068)\end{array}$ & $\begin{array}{c}-0.2139954 \\
(0.2668568)\end{array}$ & + & $\begin{array}{c}0.08496596 \\
(0.3733633)\end{array}$ & + & \\
\hline$C P I$ & $\begin{array}{l}1.5147627^{* *} \\
(1.0096325)\end{array}$ & $\begin{array}{l}0.9439989^{* * *} \\
(0.7631568)\end{array}$ & $\begin{array}{l}1.5295353^{* *} \\
(1.0865966)\end{array}$ & + & $\begin{array}{l}0.9563441^{* * *} \\
(0.7865602)\end{array}$ & + & \\
\hline ESI & $\begin{array}{l}1.6886326^{* *} \\
(0.9539965)\end{array}$ & $\begin{array}{l}1.0400391^{\text {*** }} \\
(0.7583232)\end{array}$ & $\begin{array}{l}1.6985658^{* * *} \\
(0.9556541)\end{array}$ & + & $\begin{array}{l}1.0596503^{* * *} \\
(0.7709161)\end{array}$ & + & \\
\hline $\begin{array}{l}\text { Country control } \\
\text { Robustness Check } \\
\text { by regions }\end{array}$ & controlled & controlled & controlled & & controlled & & \\
\hline $\begin{array}{l}\text { Pseudo } R^{2} \\
\text { p-value }\end{array}$ & $\begin{array}{l}0.047 \\
0.000\end{array}$ & $\begin{array}{l}0.052 \\
0.00\end{array}$ & & & & & $\begin{array}{r}\text { Table } 5 . \\
\text { Results of statistical }\end{array}$ \\
\hline \multicolumn{7}{|c|}{ Notes: ${ }^{*} p$ value $<0.1$ and ${ }^{* *} p$ value $<0.05$} & analysis \\
\hline
\end{tabular}

In line with the stakeholders' theory and previous studies (Sellami et al., 2019), our study robustly demonstrates that a higher percentage of women directors in the $\mathrm{BoD}$ strengthens the adoption of SDG practices and external assurance of sustainability reporting. Furthermore, our findings reveal that organisations operating in industries sensitive to the environment and with high consumer closeness are more likely to adopt SDG reporting and external assurance to enhance their reputation and reduce the public awareness of the larger effect that their activity has on the environment.

Secondly, this study contributes to the corporate governance literature by investigating the impact of corporate governance factors - including the board gender diversity - on sustainability reporting and external assurance in low and middle-income countries in Asia and Africa. Overall, the analysis in our paper provides evidence that board gender diversity has a positive significant association with sustainability reporting practices and external assurance. This is consistent with the view that female board representation affects corporate reporting activity. 
GM

36,7

816

Finally, this study addresses the understudied question of how board gender diversity affects the adoption of external assurance, providing suggestions for further research in the field of assurance of sustainability reporting.

Whilst we are careful to keep in mind that there are limitations to the generalisability of our results outside of this context, they provide some preliminary practical insights for organisations and policymakers to overcome the gender inequalities in the $\mathrm{BoD}$ that the prior literature has documented and promote sustainability reporting practices amongst large organisations in Africa and Asia.

Our research has important implications for organisations and their corporate governance practices.

Sustainability reports and their external assurance are considered as key tools in defining sustainability policies whilst representing organisational control mechanisms able to foster the strategic incorporation of sustainability into the firms (Kuzey and Uyar, 2017).

Our findings are useful for the director selection process as the results highlight the importance of considering the board gender diversity. As women's decisions tend to be more socially oriented than men's, they contribute to a more effective address to sustainability practices and stakeholder needs. Therefore, a greater presence of women in the $\mathrm{BoD}$ could provide support to the challenges faced by the top management of large Asian and African organisations in ensuring their increasing engagement in sustainability initiatives whilst acting in the best interest of the company and its stakeholders. Hence, organisations should establish policies concerning boardroom gender diversity and set measurable objectives for their implementation.

A second implication emerges from this study.

The results show that board diversity has benefits to firms with respect to SDG reporting and external assurance regardless of region and that Asian and African women are equally capable of improved firm performance. Therefore, governments should remove the barriers at the root of the historic inequality in women board representation in the African and Asian regions. A greater presence of women on the $\mathrm{BoD}$ would increase organisations' commitment to sustainability practices especially in countries such as Asia and Africa where the absence of sufficiently binding national regulations often turns into unethical behaviour and business practices.

Furthermore, as an understanding of the concept and importance of sustainability is still lacking amongst certain developing countries, governments should promote the incorporation of sustainability practices in companies' values and culture whilst empowering local communities and transforming them into legitimate and powerful stakeholders.

Going forward, future research could expand the experimental setting of our study by including other factors such as the socioeconomic-cultural context and investigate whether our results continue to hold in different contexts, particularly in emerging funding contexts. Furthermore, future research could investigate other factors related to the adoption of external assurance of sustainability reporting such as the quality of the assurance, the assurance level or the type of assurance providers.

\section{Notes}

1. Organisations are classified as "large" based on the European (EU) definition of size, i.e. organisations with a headcount of at least 250 , an annual turnover greater than $€ 50 \mathrm{~m}$ or a balance sheet total of more than $€ 43 \mathrm{~m}$. According to the World Bank classification, lower-middleincome economies are defined as those with a gross national income (GNI) per capita, calculated using the World Bank Atlas method, between $\$ 996$ and $\$ 3,895$. 
2. Amongst the major providers of sustainability reporting guidance, the GRI's Sustainability Reporting Standards are the most adopted frameworks for voluntary reporting worldwide (Brown et al., 2009).

\section{Gender diversity on corporate boards}

\section{References}

Adams, R.B. and Ferreira, D. (2009), "Women in the boardroom and their impact on governance and performance", Journal of Financial Economics, Vol. 94 No. 2, pp. 291-309.

Ali, W., Frynas, J.G. and Mahmood, Z. (2017), "Determinants of corporate social responsibility (CSR) disclosure in developed and developing countries: a literature review", Corporate Social Responsibility and Environmental Management, Vol. 24 No. 4, pp. 273-294.

Al-Shaer, H. and Zaman, M. (2016), "Board gender diversity and sustainability reporting quality", Journal of Contemporary Accounting and Economics, Vol. 12 No. 3, pp. 210-222.

Ameer, R. and Othman, R. (2012), "Sustainability practices and corporate financial performance: a study based on the top global corporations", Journal of Business Ethics, Vol. 108 No. 1, pp. 61-79.

Anazonwu, H.O., Egbunike, F.C. and Gunardi, A. (2018), "Corporate board diversity and sustainability reporting: a study of selected listed manufacturing firms in Nigeria", Indonesian Journal of Sustainability Accounting and Management, Vol. 2 No. 1, pp. 65-78.

Arayssi, M., Dah, M. and Jizi, M. (2016), "Women on boards, sustainability reporting and firm performance", Sustainability Accounting, Management and Policy Journal, Vol. 7 No. 3, pp. 376-401.

Barua, A., Davidson, L.F., Rama, D.V. and Thiruvadi, S. (2010), "CFO gender and accruals quality", Accounting Horizons, Vol. 24 No. 1, pp. 25-39.

Bear, S., Rahman, N. and Post, C. (2010), "The impact of board diversity and gender composition on corporate social responsibility and firm reputation", Journal of Business Ethics, Vol. 97 No. 2, pp. 207-221.

Ben-Amar, W., Chang, M. and McIlkenny, P. (2017), "Board gender diversity and corporate response to sustainability initiatives: evidence from the carbon disclosure project", Journal of Business Ethics, Vol. 142 No. 2, pp. 369-383.

Bepari, M.K. and Mollik, A.T. (2016), "Stakeholders' interest in sustainability assurance process: an examination of assurance statements reported by Australian companies", Managerial Auditing Journal, Vol. 31 Nos 6/7, pp. 655-687.

Branco, M.C. and Rodrigues, L.L. (2008), "Factors influencing social responsibility disclosure by Portuguese companies", Journal of Business Ethics, Vol. 83 No. 4, pp. 685-701.

Broberg, P., Tagesson, T. and Collin, S.O. (2010), "What explains variation in voluntary disclosure? A study of the annual reports of corporations listed on the Stockholm stock exchange", Journal of Management and Governance, Vol. 14 No. 4, pp. 351-377.

Brown, H.S., De Jong, M. and Levy, D.L. (2009), "Building institutions based on information disclosure: lessons from GRI's sustainability reporting”, Journal of Cleaner Production, Vol. 17 No. 6, pp. 571-580.

Cho, C.H., Michelon, G., M. Patten, D. and W. Roberts, R. (2014), "CSR report assurance in the USA: an empirical investigation of determinants and effects", sustainability accounting", Sustainability Accounting, Management and Policy Journal, Vol. 5 No. 2, pp. 130-148.

Cohen, J.R., Holder-Webb, L.L., Nath, L. and Wood, D. (2012), “Corporate reporting of nonfinancial leading indicators of economic performance and sustainability", Accounting Horizons, Vol. 26 No. 1, pp. 65-90.

Deloitte (2019), "Women in the boardroom: a global perspective - 6th edition".

Elmagrhi, M.H., Ntim, C.G. and Wang, Y. (2016), "Antecedents of voluntary corporate governance disclosure: a post-2007/08 financial crisis evidence from the influential UK combined code", Corporate Governance, Vol. 16 No. 3, pp. 507-538. 
GM

36,7

Fernandez-Feijoo, B., Romero, S. and Ruiz-Blanco, S. (2014a), "Effect of stakeholders' pressure on transparency of sustainability reports within the GRI framework", Journal of Business Ethics, Vol. 122 No. 1, pp. 53-63.

Fernandez, Feijoo, B., Romero, S. and Ruiz-Blanco, S. (2014b), "Women on boards: do they affect sustainability reporting?", Corporate Social Responsibility and Environmental Management, Vol. 21 No. 6, pp. 351-364.

Fraser-Moleketi, G.J. and Mizrahi, S. and African Development Bank (2015), Where Are the Women: Inclusive Boardrooms in Africa's Top Listed Companies, African Development Bank.

Galbreath, J. (2011), "Are there gender-related influences on corporate sustainability? A study of women on boards of directors", Journal of Management and Organization, Vol. 17 No. 1, pp. 17-38.

García-Sánchez, I.M., Suárez-Fernández, O. and Martínez-Ferrero, J. (2019), "Female directors and impression management in sustainability reporting", International Business Review, Vol. 28 No. 2, pp. 359-374.

Girón, A., Kazemikhasragh, A., Cicchiello, A.F. and Panetti, E. (2020), "Sustainability reporting and firms' economic performance: Evidence from Asia and Africa", Journal of the Knowledge Economy, pp. 1-19.

Glass, C., Cook, A. and Ingersoll, A.R. (2015), "Do women leaders promote sustainability? Analyzing the effect of corporate governance composition on environmental performance”, Business Strategy and the Environment, Vol. 25 No. 7, pp. 495-511.

Global Reporting Initiative (2013), The External Assurance of Sustainability Reporting, Amsterdam: GRI.

Global Reporting Initiative (2018), Business Reporting on the SDGs, Amsterdam: GRI.

Gul, F., Srinidhi, B. and Anthony, C.N. (2011), "Does board gender diversity improve the informativeness of stock prices?", Journal of Accounting and Economics, Vol. 51 No. 3, pp. 314-338.

Hahn, R. and Kühnen, M. (2013), "Determinants of sustainability reporting: a review of results, trends, theory, and opportunities in an expanding field of research", Journal of Cleaner Production, Vol. 59, pp. 5-21.

Haque, F. (2017), "The effects of board characteristics and sustainable compensation policy on carbon performance of UK firms", The British Accounting Review, Vol. 49 No. 3, pp. 347-364.

Harjoto, M., Laksmana, I. and Lee, R. (2015), "Board diversity and corporate social responsibility", Journal of Business Ethics, Vol. 132 No. 4, pp. 641-660.

Ho, S.S.M., Li, A.Y., Tam, K. and Zhang, F.F. (2014), “CEO gender, ethical leadership, and accounting conservatism”, Journal of Business Ethics, Vol. 127 No. 2, pp. 351-370.

Issa, A. and Fang, H.X. (2019), "The impact of board gender diversity on corporate social responsibility in the arab Gulf states", gender in management", Gender in Management: An International Journal, Vol. 34 No. 7, pp. 577-605.

Jamali, D. and Karam, C. (2018), "Corporate social responsibility in developing countries as an emerging field of study”, International Journal of Management Reviews, Vol. 20 No. 1, pp. 32-61.

Jianakoplos, N.A. and Bernasek, A. (1998), “Are women more risk averse?”, Economic Inquiry, Vol. 36 No. 4, pp. 620-630.

Jizi, M. (2017), "The influence of board composition on sustainable development disclosure", Business Strategy and the Environment, Vol. 26 No. 5, pp. 640-655.

Kiliç, M., Kuzey, C. and Uyar, A. (2015), "The impact of ownership and board structure on corporate social responsibility (CSR) reporting in the Turkish banking industry", Corporate Governance, Vol. 15 No. 3, pp. 357-374.

Kolk, A. and Perego, P. (2010), "Determinants of the adoption of sustainability assurance statements: an international investigation", Business Strategy and the Environment, Vol. 19 No. 3, pp. 182-198. 
Kuzey, C. and Uyar, A. (2017), "Determinants of sustainability reporting and its impact on firm value: Evidence from the emerging market of Turkey”, Journal of Cleaner Production, Vol. 143, pp. 27-39.

Lattemann, C., Fetscherin, M., Alon, I., Li, S. and Schneider, A.M. (2009), "CSR communication intensity in Chinese and Indian multinational companies", Corporate Governance: An International Review, Vol. 17 No. 4, pp. 426-442.

Liao, L., Lin, T.P. and Zhang, Y. (2018), "Corporate board and corporate social responsibility assurance: Evidence from China”, Journal of Business Ethics, Vol. 150 No. 1, pp. 211-225.

Liao, L., Luo, L. and Tang, Q. (2015), "Gender diversity, board independence, environmental committee and greenhouse gas disclosure", The British Accounting Review, Vol. 47 No. 4, pp. 409-424.

$\mathrm{Lu}, \mathrm{X}$. and White, H. (2014), "Robustness checks and robustness tests in applied economics", Journal of Econometrics, Vol. 178, pp. 194-206.

McGuinness, P.B., Vieito, J.P. and Wang, M. (2017), "The role of board gender and foreign ownership in the CSR performance of Chinese listed firms", Journal of Corporate Finance, Vol. 42, pp. 75-99.

Mahmood, Z., Kouser, R., Ali, W., Ahmad, Z. and Salman, T. (2018), "Does corporate governance affect sustainability disclosure? A mixed methods study”, Sustainability, Vol. 10 No. 1, p. 207.

Neumayer, E. and Plümper, T. (2017), Robustness Tests for Quantitative Research, Cambridge University Press.

Nguyen, T.H.H., Ntim, C.G. and Malagila, J.K. (2020), "Women on corporate boards and corporate financial and non-financial performance: a systematic literature review and future research agenda", International Review of Financial Analysis, Vol. 17, pp. 1-24.

Osazuwa, N.P., Che-Ahmad, A. and Che-Adam, N. (2016), "Board characteristics and environmental disclosure in Nigeria”, Information (Japan), Vol. 19 No. 18A, pp. 3069-3074.

Peters, G.F. and Romi, A.M. (2015), "The association between sustainability governance characteristics and the assurance of corporate sustainability reports", Auditing: A Journal of Practice and Theory, Vol. 34 No. 1, pp. 163-198.

Post, C., Rahman, N. and Rubow, E. (2011), "Green governance: Boards of directors' composition and environmental corporate social responsibility", Business and Society, Vol. 50 No. 1, pp. 189-223.

Rao, K. and Tilt, C. (2015), "Board composition and corporate social responsibility: the role of diversity, gender, strategy and decision making”, Journal of Business Ethics, Vol. 130 No. 5, pp. 1-21.

Rao, K.K., Tilt, C.A. and Lester, L.H. (2012), "Corporate governance and environmental reporting: an Australian study", Corporate Governance: The International Journal of Business in Society, Vol. 12 No. 2, pp. 143-163.

Reverte, C. (2009), "Determinants of corporate social responsibility disclosure ratings by spanish listed firms", Journal of Business Ethics, Vol. 88 No. 2, pp. 351-366.

Rosati, F. and Faria, L.G.D. (2019), "Business contribution to the sustainable development agenda: Organizational factors related to early adoption of SDG reporting", Corporate Social Responsibility and Environmental Management, Vol. 26 No. 3, pp. 588-597.

Saggar, R. and Singh, B. (2017), "Corporate governance and risk reporting: Indian evidence", Managerial Auditing Journal, Vol. 32 Nos 4/5, pp. 378-405.

Sellami, Y.M., Hlima, N.D.B. and Jarboui, A. (2019), "An empirical investigation of determinants of sustainability report assurance in France", Journal of Financial Reporting and Accounting, Vol. 17 No. 2, pp. 320-342.

Setó-Pamies, D. (2015), "The relationship between women directors and corporate social responsibility", Corporate Social Responsibility and Environmental Management, Vol. 22 No. 6, pp. 334-345.

Sharif, M. and Rashid, K. (2014), "Corporate governance and corporate social responsibility (CSR) reporting: an empirical evidence from commercial banks (CB) of Pakistan”, Quality and Quantity, Vol. 48 No. 5, pp. 2501-2521.

Simnett, R., Vanstraelen, A. and Chua, W.F. (2009), "Assurance on sustainability reports: an international comparison”, The Accounting Review, Vol. 84 No. 3, pp. 937-967.

\section{Gender \\ diversity on \\ corporate \\ boards}


GM

36,7

Tilt, C.A., Qian, W., Kuruppu, S. and Dissanayake, D. (2020), "The state of business sustainability reporting in Sub-Saharan Africa: an agenda for policy and practice", sustainability accounting", Sustainability Accounting, Management and Policy Journal, Vol. 12 No. 2.

Tourigny, L., Han, J. and Baba, V.V. (2017), "Does gender matter? A study of trust and its outcomes in the manufacturing sector in mainland China", gender in management", Gender in Management: An International Journal, Vol. 32 No. 8, pp. 554-577.

Velte, P. (2017), "Do women on board of directors have an impact on corporate governance quality and firm performance? A literature review", International Journal of Sustainable Strategic Management, Vol. 5 No. 4, pp. 302-346.

Velte, P. and Stawinoga, M. (2017), "Empirical research on corporate social responsibility assurance (CSRA): a literature review", Journal of Business Economics, Vol. 87 No. 8, pp. 1017-1066.

Williams, R.J. (2003), "Women on corporate boards of directors and their influence on corporate philanthropy", Journal of Business Ethics, Vol. 42 No. 1, pp. 1-10.

World Economic Forum (2018), The Global Gender Gap Report 2018, World Economic Forum, Switzerland.

Yasser, Q.R., Al Mamun, A. and Ahmed, I. (2017), "Corporate social responsibility and gender diversity: insights from Asia pacific", Corporate Social Responsibility and Environmental Management, Vol. 24 No. 3, pp. 210-221.

Zaichkowsky, J.L. (2014), "Women in the board room: One can make a difference", International Journal of Business Governance and Ethics, Vol. 9 No. 1, pp. 91-113.

Zhang, L. (2012), "Board demographic diversity, independence, and corporate social performance", Corporate Governance: The International Journal of Business in Society, Vol. 12 No. 5, pp. 686-700.

\section{Further reading}

Ball, A., Owen, D.L. and Gray, R. (2000), "External transparency or internal capture? The role of thirdparty statements in adding value to corporate environmental reports", Business Strategy and the Environment, Vol. 9 No. 1, pp. 1-23.

\section{Corresponding author}

Antonella Francesca Cicchiello can be contacted at: antonella.cicchiello@unicatt.it

For instructions on how to order reprints of this article, please visit our website: 